\title{
RADOSLAW RYBKOWSKI
}

Uniwersytet Jagielloński

ORCID: 0000-0002-2556-6698

\section{Stosunki międzynarodowe w szkole wyższej. Praktyka}

\section{Studies in international relations in practice}

In the tradition of Polish higher education institutions, study programmes in international relations are treated as part of political science and so they focus more on theoretical issues The experience of foreign universities proves that particularly studies in international relations could and should emphasise the applicability of knowledge and skills acquired during the studies. The practice of the members of the Guild of European Research-Intensive Universities (The Guild) shows that these programmes should involve investigating and solving actual problems. Only thanks to the collaboration with public and private entities involved in transnational and cross-border activities, students can appreciate the applicability of theories and understand that every good theory must be based on genuine experience. Thus, the programmes offered by European universities can show how to enhance the quality of Polish study programmes in the field of international relations.

Keywords: international relations, higher education, practical education, research-based programmes

Słowa kluczowe: stosunki międzynarodowe, szkolnictwo wyższe, profil praktyczny, profil ogólnoakademicki, kształcenie w oparciu o badania

\section{Stosunki międzynarodowe w reformowanym szkolnictwie wyższym}

Na krótko przed odbywającym się w Krakowie Narodowym Kongresem Nauki w Ministerstwie Nauki i Szkolnictwa Wyższego odbyła się publiczna prezentacja przygotowanego przez międzynarodową grupę ekspertów Komisji Europejskiej raportu Poland's higher education and science system. Horizon 2020 policy support facility ${ }^{1}$. Dokument ten dotyczył systemu nauki i szkolnictwa wyższego

1 European Commission, Peer review. Poland's higher education and science system. Horizon 2020 policy support facility, Publication Office of the European Union, Luxembourg 2017. 
jako całości i z oczywistych względów nie mógł potraktować nauczania stosunków międzynarodowych w żaden szczególny sposób. Uczestniczący w spotkaniu autorzy zwrócili uwagę, że polski system cechują niezwykłe rozdrobnienie i brak sensownego zróżnicowania wewnętrznego. Rezultatem takiego stanu rzeczy jest wspólna niemal wszystkim rodzimym uczelniom chęć osiągnięcia statusu poważanej placówki badawczej przy jednoczesnym oferowaniu zaskakująco zbieżnych programów nauczania² ${ }^{2}$.

Wydawać by się mogło, że powyższa uwaga niekoniecznie dotyczy oferowanych przez polskie uczelnie programów studiów w zakresie stosunków międzynarodowych, ale dane dostępne w Ogólnopolskim Systemie Monitorowania Ekonomicznych Losów Absolwentów Szkół Wyższych (ELA) powinny studzić nadmierny optymizm. Gdyby wziąć pod uwagę jedynie absolwentów studiów stacjonarnych, którzy zakończyli naukę w roku 2016, to okaże się, że w Polsce funkcjonowały 33 programy na studiach pierwszego stopnia i 21 na studiach drugiego stopnia ${ }^{3}$. Należy przy tym pamiętać, że znaczna część uczelni oferuje pełen cykl kształcenia. Położenie państwa polskiego, jego populacja i rosnące znaczenie gospodarcze powodują, że powinno być ono aktywnym podmiotem na arenie międzynarodowej, ale mimo to należy zadać pytanie, czy uzasadniona jest aż tak duża liczba programów, a to powinno rodzić kolejne - jaki jest sens i jaki powinien być cel kształcenia studentów stosunków międzynarodowych.

W polskim reżimie prawnym uczelnie mogą oferować programy studiów na profilach ogólnoakademickim oraz praktycznym. Definicje zawarte w ustawie Prawo o szkolnictwie wyższym i nauce są jednak bardzo ogólne. Studia ogólnoakademickie to takie, na których ,ponad połowa punktów ECTS jest przypisana zajęciom związanym z prowadzoną w uczelni działalnością naukową" (art. 64, ust. 2, pkt 2). Dodatkowym wymaganiem nakładanym przepisami prawa jest obowiązek, by „,co najmniej 75\% godzin zajęć prowadzonych [było] przez nauczycieli akademickich zatrudnionych w tej uczelni jako podstawowym miejscu pracy" (art. 73, ust. 2, pkt 2). Ustawa równie lakonicznie odnosi się do profilu praktycznego, w przypadku którego ,ponad połowa punktów ECTS jest przypisana zajęciom kształtującym umiejętności praktyczne” (art. 64, ust. 2, pkt 1), a „co najmniej 50\% godzin zajęć prowadzonych

2 R. Rybkowski, M. Kędzierski, Zawodówki: reaktywacja. Rola wyższych szkót zawodowych w rozwoju spoleczno-gospodarczym Polski, Centrum Analiz Klubu Jagiellońskiego, Kraków 2017 (Raport, 4/2017), s. 16-17.

3 Zob. Program. Wskaźniki, dostępny w internecie [dostęp: 1 IX 2019]: <https://ela.nauka. gov.pl/assets/csv/file/P1.csv>. 
jest przez nauczycieli akademickich zatrudnionych w tej uczelni jako podstawowym miejscu pracy" (art. 73, ust. 2, pkt 1) $)^{4}$.

Przepisy wykonawcze zawarte w Rozporzadzeniu Ministra Nauki i Szkolnictwa Wyższego [...] w sprawie studiów w niewielkim stopniu precyzują, na czym ma polegać istotna różnica pomiędzy obydwoma profilami, i nie dają odpowiedzi na pytanie, czy profile mogą być jednocześnie praktyczne i ogólnoakademickie. Jedynym istotnym wyjaśnieniem jest to, że studia na profilu ogólnoakademickim powinny uwzględniać „udział studentów w zajęciach przygotowujących do prowadzenia działalności naukowej lub udział w tej działalności” (par. 3, ust. 5, pkt 2) . Takie definiowanie praktyczności i akademickości kształcenia ma poważne konsekwencje dla kierunków zaliczanych do dziedziny nauk społecznych. Mimo że zjawiska społeczne z natury bardzo często mają poważne konsekwencje praktyczne, to jednak polskie ośrodki prowadzące studia o profilu ogólnoakademickim zazwyczaj więcej miejsca poświęcają teorii i metodzie niż możliwości wykorzystania prowadzonych badań w praktyce. Inspiracją do wprowadzania stopniowych zmian w programach kształcenia może być dla nich poznanie rozwiązań wykorzystywanych w krajach należących do Europejskiego Obszaru Szkolnictwa Wyższego.

W Polsce jedną ze szkół oferujących pełen kurs stosunków międzynarodowych jest Uniwersytet Jagielloński (UJ). Będący jego częścią Instytut Nauk Politycznych i Stosunków Międzynarodowych kształci na tym kierunku od ponad dwudziestu lat, co w końcu doprowadziło do zmiany nazwy jednostki, by dowartościować prowadzone badania i zajęcia dydaktycz$\mathrm{ne}^{6}$. Od $2016 \mathrm{r}$. UJ jest wspólnie z osiemnastoma innymi uczelniami częścią The Guild of European Research-Intensive Universities (The Guild). Dzięki aktywnemu uczestnictwu w pracach tej organizacji ma łatwy dostęp do doświadczeń badawczych i edukacyjnych wielu ośrodków akademickich legitymujących się znakomitymi osiągnięciami w wykładaniu nauk o polityce (i administracji, jak chciałby obecny wykaz), w tym stosunków międzynarodowych, będących głównym przedmiotem zainteresowania w niniejszym artykule? ${ }^{7}$.

4 Ustawa z dnia 20 lipca 2018 roku - Prawo o szkolnictwie wyższym i nauce, Dz.U. 2018, poz. 1668 z późn. zm.

5 Rozporządzenie Ministra Nauki i Szkolnictwa Wyższego z dnia 27 września 2018 roku w sprawie studiów, Dz.U. 2018, poz. 1861.

6 Dla kandydatów, „Instytut Nauk Politycznych i Stosunków Międzynarodowych Uniwersytetu Jagiellońskiego" [online, dostęp: 1 IX 2019], dostępny w internecie: <https://inp. uj.edu.pl/kandydaci>.

7 Promoting research and innovation across Europe. Founding vision, „The Guild” [online, dostęp: 1 IX 2019], dostępny w internecie: <https://www.the-guild.eu/about/vision/ the-guild---founding-vision.pdf $>$. 


\section{Rozwiązania kontynentalnej Europy}

Uczelnią, która bardzo mocno podkreśla związki stosunków międzynarodowych z naukami politycznymi, jest holenderski Rudboud University (zajmujący pozycję 101-150 w rankingu szanghajskim, a 151-200 pod kątem nauk politycznych ${ }^{8}$ ). Oferowany tam roczny program International Relations jest po prostu specjalnością możliwą do zrealizowania na drugim stopniu magisterskich studiów Political Science, obok takich innych specjalności, jak np. Political Theory czy Comparative Politics9. Uniwersytet chwali się na swoich stronach internetowych, że jego program stosunków międzynarodowych pozwala na zdobycie wiedzy i praktycznych umiejętności, które można łatwo wykorzystać na rynku pracy. Podkreśla się przy tym, że w ramach obowiązkowych kursów studenci zapoznają się z „narzędziami niezbędnymi do projektowania metodologicznie uzasadnionych badań w zakresie nauk politycznych oraz poznają, w jaki sposób krytycznie oceniać jakość metod $\mathrm{i}$ analiz zastosowanych $\mathrm{w}$ raportach i dokumentach politycznych"

Oczywiście trudno wyobrazić sobie uczelnię, która nie zachwalałaby własnych studiów, ale ten głos autopromocji znalazł potwierdzenie w raporcie Nederlands-Vlaamse Accreditatieorganisatie (NVAO), czyli holendersko-flamandzkiego odpowiednika Polskiej Komisji Akredytacyjnej. W raporcie z 2017 r. za jedną z najważniejszych cech programu studiów uznano w NVAO „łączenie umiejętności badawczych z wykorzystaniem praktycznym, co podkreśla znaczenie dla rynku pracy dobrego, opartego na badaniach przygotowania metodologicznego i teoretycznego" ${ }^{11}$. Kluczowy dla zapewnienia praktyczności kierunku był kurs Advanced Research Methods ('Zaawansowane Metody Badawcze'), o którym z uznaniem wypowiadali się studenci, a ab-

8 Academic ranking of world universities 2019, „Academic Ranking of World Universities” [online, dostęp: 1 IX 2019], dostępny w internecie: <http://www.shanghairanking.com/ ARWU2019.html>.

9 Master's specialisation in International Relations, „Rudboud University” [online, dostęp: 1 IX 2019], dostępny w internecie: <https://www.ru.nl/english/education/masters/ international-relations/>.

10 Curriculum and courses, „Rudboud University” [online, dostęp: 1 IX 2019], dostępny w internecie: <https://www.ru.nl/english/education/masters/international-relations/ curriculum-and-courses/ $>$.

11 Political science. Nijmegen School of Management: Radboud University, QANU, Utrecht 2017, s. 10, dostępny również w internecie [dostęp: 1 IX 2019]: <https://search. nvao.net/files/5a93fd067337d_006099\%20 r.pport\%20Radboud\%20wo-ma\%20Political\%20Science.pdf>. 
solwenci zgodnie przyznawali, że umiejętności nabyte w czasie tych zajęć wykorzystują w codziennej pracy ${ }^{12}$. Na podstawie dostępnych dokumentów dotyczących relacji międzynarodowych (np. z zakresu dyplomacji, problemu migracji czy działań programów pomocowych) studenci poznają i stosują metody oceny skuteczności podejmowanych działań, co jest niezbędne do ich efektywnego planowania w przyszłości.

Inne podejście do nauczania stosunków międzynarodowych prezentuje Uniwersytet w Oslo (59 miejsce w rankingu szanghajskim, a 43 - pod kątem nauk politycznych), w ofercie którego w ogóle nie ma kierunku ani nawet specjalności o takiej nazwie. Osoby zainteresowane lepszym zrozumieniem współczesnego świata i pracą w obszarze relacji międzynarodowych mogą zamiast tego skorzystać $\mathrm{z}$ dwóch dwuletnich programów studiów magisterskich - Peace and Conflict Studies ('Studia nad Pokojem i Konfliktami') $)^{13}$ oraz Development, Environment and Cultural Change ('Rozwój, Środowisko i Przemiany Kulturowe') ${ }^{14}$. O ile nazwa pierwszego nie budzi wątpliwości, bo większość polskich programów stosunków międzynarodowych oferuje rozbudowane kursy nt. przeciwdziałania konfliktom, to już połączenie kultury, środowiska i rozwoju wydaje się odległe od nauk o polityce i administracji. W odniesieniu do Peace and Conflict Studies w procesie ewaluacji programu zwrócono uwagę, że jest on nazbyt mocno zakorzeniony $\mathrm{w}$ dyscyplinie nauk o polityce, więc przy otwartym dostępie do tych studiów dla absolwentów kierunków niezwiązanych z politologią stawiane wymagania mogą się okazać zbyt duże ${ }^{15}$. W programie Development, Environment and Cultural Change kluczowym przedmiotem obowiązkowym jest Research Method and Project Design ('metoda badawcza i planowanie badań'). Takie fakultatywne przedmioty, jak Latin American Politics and Development czy Global Governance and Sustainable Development bazują na umiejętnościach badawczych nabytych

12 Tamże, s. 16.

13 Why choose this programme? [Peace and Conflict Studies], „University of Oslo” [online, dostęp: 1 IX 2019], dostępny w internecie: <https://www.uio.no/english/studies/ programmes/peace-master/why-choose/>.

14 Why choose this programme? [Development, Environment and Cultural Change], „University of Oslo" [online, dostęp: 1 IX 2019], dostępny w internecie: <https://www.uio.no/ english/studies/programmes/ces-master/why-choose/>.

15 Periodisk programevaluering av Master of Philosophy in Peace and Conflict Studies (PECOS), „Oslo University” [online, dostęp: 1 IX 2019], dostępny w internecie: <https:// www.uio.no/english/studies/programmes/peace-master/programevaluering/Periodisk. programevaluering $06>$. 
w czasie pierwszego semestru, by w ciągu ostatniego roku studenci mogli się poświęcić tylko i wyłącznie przygotowaniu pracy magisterskiej. Wobec braku innych zajęć magistranci mają możliwość i obowiązek przeprowadzenia badań w oparciu o rzeczywiste zjawiska zachodzące we współczesnym świecie. W ten sposób program studiów ma wprowadzić właściwą proporcję pomiędzy mocno zredukowaną teorią a praktyką, której poświęcona ma być praca magisterska ${ }^{16}$.

$\mathrm{Na}$ Uniwersytecie Eberharda Karola w Tybindze (pozycja 151-200 w rankingu, a 201-300 pod kątem nauk politycznych), podobnie jak w Oslo, dokonano połączenia studiów nad pokojem ze stosunkami międzynarodowymi, tworząc dwuletni program International Relations / Peace and Conflict Reserach ('Stosunki Międzynarodowe / Badania nad Pokojem i Konfliktami'). Niemiecka uczelnia w dużo większym stopniu podkreśla jednak praktyczny wymiar oferowanych studiów, co jest głównym atutem całego tamtejszego Instytutu Nauk Politycznych. Mamy tu więc do czynienia ze zrównoważonym modelem kształcenia, bo z jednej strony jest ono mocno oparte na teorii, uwzględnia interdyscyplinarność w badaniach nad stosunkami międzynarodowymi i pokojem, ale z drugiej jako podstawę zdobywania wykształcenia traktuje praktykę. Dzięki takiemu podejściu studenci mogą uczestniczyć w symulacji prac Organizacji Narodów Zjednoczonych, a dogodne położenie uczelni pozwala na cykliczne organizowanie wyjazdów studyjnych do Wiednia, Genewy, Strasbourga i Brukseli, podczas których można się przekonać, na czym polega współczesna dyplomacja i zarządzanie porządkiem międzynarodowym ${ }^{17}$. Zajęcia w ramach programu International Relations / Peace and Conflict Reserach realizowane są zgodnie z polską wizją studiów ogólnoakademickich. Studenci korzystają z badań Centrum Badań nad Pokojem i są w nie wprowadzani. Współdziałając z profesorami Uniwersytetu w Tybindze, poznają warunki stabilnej współpracy międzynarodowej oraz pokojowego rozwiązywania konfliktów, badają rolę religii w powstawaniu konfliktów politycznych czy też analizują współczesne przemiany koncepcji granic pań-

16 Programme structure, „University of Oslo” [online], 12 X 2018 [dostęp: 1 IX 2019], dostępny w internecie: <https://www.uio.no/english/studies/programmes/ces-master/structure/>.

17 Description of Master's Programme „,Peace and Conflict Studies and International Relations”, „University of Tübingen” [online, dostęp: 1 IX 2019], dostępny w internecie: $<$ https://uni-tuebingen.de/en/faculties/faculty-of-economics-and-social-sciences/subjects/department-of-social-sciences/ifp/institute-of-political-science/people/ipol/course-programme/master-peace-research-and-international-politics/description-of-mastersprogramm-peace-and-conflict-research-and-international-relations/>. 
stwowych $^{18}$. Sukcesy zawodowe absolwentów tego kierunku - zatrudnionych w takich instytucjach, jak np. Organizacja Bezpieczeństwa i Współpracy w Europie, UNESCO, niemieckie Ministerstwo Spraw Zagranicznych czy amerykański Departament Stanu - wyraźnie pokazują, że w Tybindze udało się sprawnie połączyć studia akademickie ze zdobywaniem niezbędnych w pracy zawodowej umiejętności praktycznych.

\section{Model brytyjski i kodeks dobrych praktyk kształcenia na kierunkach badawczych}

Uniwersytet w Glasgow (miejsce 151-200 w rankingu szanghajskim oraz 101-150 wśród dyscyplin z dziedziny nauk politycznych) ma w swojej ofercie roczny program studiów International Relations, zgodny z brytyjską tradycją kształcenia uniwersyteckiego. W założeniu ma on wyposażyć absolwentów w umiejętność „wykorzystywania odpowiednich metod badawczych oraz prowadzenia dobrze zaplanowanych analiz danych świata polityki" ${ }^{\prime 9}$. Studia te mają umożliwić słuchaczom rozumienie współczesnego świata i międzynarodowych powiązań, a jednocześnie służyć wykształceniu umiejętności i kompetencji, które mogą być wykorzystane na współczesnym rynku pracy. Badanie problemów polityki międzynarodowej nie staje się celem samym w sobie; dzięki naciskowi na umiejętności komunikacyjne absolwenci są dobrze przygotowani do tłumaczenia problemów współczesnego zglobalizowanego świata całemu społeczeństwu.

Mając na uwadze praktyczne cele kształcenia, w programie stosunków międzynarodowych rozwija się współpracę z instytucjami międzynarodowymi, ze szczególnym uwzględnieniem organizacji działających w samym Glasgow. Dzięki temu już na studiach można współpracować i prowadzić badania m.in. z Global Security Roundtable, Global Security Network, Glasgow Center for International Development czy Glasgow Refugee, Asylum and Migration Network. Co roku organizowana jest też trzydniowa wizyta

18 Friedensforschung damals und heute Selbstverständnis, „University of Tübingen” [online, dostęp: 1 IX 2019], dostępny w internecie: <https:/uni-tuebingen.de/fakultaeten/wirtschafts-und-sozialwissenschaftliche-fakultaet/faecher/fach-bereich-sozialwissenschaften/ifp/institut/lehrende/ipol/lehrangebot/master-friedensforschung-und-internationale-politik-mafip/friedensforschung-in-tuebingen/>.

19 International Relations MSc, „University of Glasgow” [online, dostęp: 1 IX 2019], dostępny w internecie: <https://www.gla.ac.uk/postgraduate/taught/internationalrelations/ \#tab=why $>$. 
studyjna w Brukseli, by studenci mogli poznać stosunki międzynarodowe w praktyce i budować sieć kontaktów niezbędnych w późniejszym poszukiwaniu pracy. Co istotne, wizyty te nie są zwyczajną wycieczką po mieście, ale co roku poświęca się je poznaniu jednej instytucji. W poprzednich latach były to m.in. NATO, Komisja Europejska, Bank Światowy czy przedstawicielstwo Szkocji w Brukseli - Scotland House ${ }^{20}$.

Przytaczanie przykładu uniwersytetu z Wielkiej Brytanii jest też interesujące dlatego, że inaczej niż w wielu innych systemach szkolnictwa wyższego tamtejsza agencja akredytacyjna - Quality Assurance Agency for Higher Education (QAA) poza oceną jakości oferowanych programów dydaktycznych przygotowała serię obszernych publikacji pt. UK Quality Code for Higher Education" ${ }^{21}$, co można by przetłumaczyć jako 'wskazówki jakości dla szkolnictwa wyższego'. QAA zaznacza, żeby nie traktować tych publikacji jako zbioru przepisów, które uczelnie i programy nauczania muszą spełnić, by otrzymać pozytywną ocenę, ale właśnie jako wskazówki, na co zwrócić uwagę przy tworzeniu programów studiów oraz w toku ich ciągłego ulepszania. Ponieważ International Relations na Uniwersytecie w Glasgow zaprojektowano jako studia badawcze (research degree), to swego rodzaju przewodnikiem dla uczelni jest licząca 38 stron część dotycząca studiów zbliżonych do naszego profilu ogólnoakademickiego. Inaczej jednak niż w polskim rozwiązaniu, które nakazuje, by ponad 50 proc. zajęć było powiązanych z badaniami prowadzonymi w danej uczelni, Brytyjczycy spróbowali dokładniej określić, na czym powinna polegać specyfika takich studiów, a także jak rozumieć zdobywanie w ich trakcie praktycznych umiejętności badawczych ${ }^{22}$.

W brytyjskim ujęciu badania naukowe definiowane są jako proces prowadzący do nowej, skutecznie komunikowanej wiedzy. Tak powstająca wiedza powinna mieć znaczenie dla handlu, przemysłu, władz publicznych i społeczeństwa, dlatego w procesie edukacyjnym nie bierze się pod uwagę działań polegających na typowym badaniu czy analizowaniu materiałów. Celem studiów jest uzyskiwanie nowej, użytecznej wiedzy, a żeby stała się użyteczna, niezbędne jest jej komunikowanie, m.in. za pomocą publikacji

20 Tamże.

21 UK Quality Code for Higher Education, „QAA” [online], 3 V 2018 [dostęp: 1 IX 2019], dostępny w internecie: <https://www.qaa.ac.uk/quality-code>.

22 UK Quality Code for Higher Education, part B: Assuring and enhancing academic quality, chapter B11: Research degrees, „QAA” [online, dostęp: 1 IX 2019], dostępny w internecie: <https://www.qaa.ac.uk/docs/qaa/quality-code/chapter-b11_-research-degrees. pdf?sfvrsn=5802f781_8>. Należy przy tym pamiętać, że od 1 września dla powstających programów obowiązuje już nowsza wersja. Tamże. 
(za publikowanie uznawane jest również przygotowywanie raportów objętych klauzulą tajności) ${ }^{23}$. QAA sugeruje, że uczelnie powinny stworzyć studentom środowisko umożliwiające prowadzenie tak rozumianych badań, czyli zapewnić dostęp do niezbędnych materiałów i infrastruktury oraz nadzór badań przez nauczycieli akademickich mających rozpoznawalne osiągnięcia naukowe. Na drugim stopniu studiów natomiast nie wystarczy dopilnować, by kształcenie (przekazywanie wiedzy i umiejętności) odbywało się w odpowiednich warunkach - w tamtejszym systemie decyzja o przyjęciu profilu badawczego oznacza również konieczność zadbania, by rezultaty badań studentów miały znaczenie dla światowej nauki ${ }^{24}$. Mają oni bowiem nie tylko korzystać z osiągnięć nauki, ale także ją współtworzyć. Z tego powodu każdemu studentowi musi być zapewniona możliwość współpracy z kadrą prowadzącą zaawansowane badania w obszarze jego zainteresowań. Rozwijana przez studentów wiedza musi być dyskutowana na szerszym forum, a stworzenie warunków do budowania przez studentów sieci kontaktów, które pozwoliłyby na przeprowadzenie niezbędnych spotkań, jest obowiązkiem uczelni, co może oznaczać konieczność zapewnienia niezbędnej infrastruktury technicznej (w przypadku kontaktów online) czy pomieszczeń (w tradycyjnych spotkaniach bezpośrednich). Współczesne wyzwania związane z prowadzeniem badań naukowych powodują z kolei, że już na tym etapie studenci muszą zapoznać się z mechanizmami finansowania nauki i mieć możliwość starania się o zewnętrzne środki ${ }^{25}$.

\section{Wyzwania dla nauczania stosunków międzynarodowych w Polsce}

Kodeks dobrych praktyk opracowany przez QAA bardzo dobrze pokazuje, na czym polega kluczowy polski problem w nauczaniu stosunków międzynarodowych. Programy o profilu ogólnoakademickim muszą wprawdzie przygotować studentów do prowadzenia badań, ale już samo uczestniczenie w nich nie jest wymagane, a tylko opcjonalne. Co więcej, w dziedzinach nauk społecznych czy humanistycznych nie wymaga się od absolwentów, by na zakończenie studiów drugiego stopnia wykazali się osiągnięciami badawczymi, które mogłyby zostać uznane za ważny wkład w naukę światową. W polskiej rzeczywistości takie oczekiwania stawiane są dopiero przed uczestnikami

23 Tamże, s. 6.

24 Tamże, s. 11.

25 Tamże, s. 12. 
studiów doktoranckich (od najbliższego roku akademickiego kształconymi w szkołach doktorskich ${ }^{26}$ ).

Zgodnie z przepisami ustawy Prawo o szkolnictwie wyższym $i$ nauce to Polska Komisja Akredytacyjna (PKA) jest ,instytucją działającą niezależnie na rzecz doskonalenia jakości kształcenia" (art. 251, ust. 1) i to na niej ciąży obowiązek ewaluacji jakości kształcenia (art. 241) w formie oceny programowej (dotyczącej jakości kształcenia na danym kierunku studiów w danej uczelni) lub kompleksowej (gdzie oceniana jest cała uczelnia, a wynik pozytywny oznacza akredytację wszystkich oferowanych kierunków) ${ }^{27}$. W ramach swoich uprawnień PKA przygotowała odpowiednik Quality Code for Higher Education, tzn. Wskaźniki spetnienia standardów jakości ksztatcenia, odrębnie dla profilu praktycznego i ogólnoakademickiego ${ }^{28}$. Należy jednak pamiętać, że publikacja brytyjska jest bardzo rozbudowaną wskazówką, jak należy przygotowywać programy studiów, aby studenci mieli możliwość rzeczywistego prowadzenia badań naukowych, które prowadzą do znaczących rezultatów. Polska lista wskaźników jest natomiast instrukcją, na co należy zwrócić uwagę przy ocenie istniejących programów kształcenia. Poniekąd zgodnie $\mathrm{z}$ kontynentalnym podejściem do stanowienia prawa PKA stworzyła instrukcję dostępną dla uczelni oraz ekspertów dokonujących merytorycznej oceny jakości, podczas gdy QAA przede wszystkim sugeruje, jak usprawnić proces kształcenia.

Z opublikowanych Wskaźników spetnienia standardów jakości ksztatcenia nie można wyciągnąć zbyt wielu wniosków na temat metod modyfikacji programu takich studiów jak stosunki międzynarodowe, by przygotowywać absolwentów do praktycznego rozwiązywania problemów związanych z relacjami międzynarodowymi, polityką zagraniczną czy dyplomacją. Od uczelni oczekuje się jedynie tego, by „stymulowały studentów do samodzielności” i aktywności w procesie uczenia się (wskaźnik 2.3.c), przygotowały „do prowadzenia działalności naukowej w zakresie dyscypliny lub dyscyplin, do których kierunek jest przyporządkowany, lub [umożliwiały] udział w tej działalności" (wskaźnik 2.3.d; pamiętajmy przy tym, że najczęściej dyscypliną nie są tutaj stosunki międzynarodowej, tylko nauki o polityce i administracji). Dodatkowo zaznaczono, że ,zasoby biblioteczne, informacyjne oraz

26 Zob. Ustawa z dnia 20 lipca 2018 roku..., art. 186.

27 Tamże.

28 Wskaźniki spetnienia standardów jakości ksztatcenia, „Polska Komisja Akredytacyjna” [online, dostęp: 1 IX 2019], dostępny w internecie: <http://www.pka.edu.pl/wp-content/ uploads/2019/04/OP_wskaźniki_spełnienia-standardów_24_02_final.pdf>. 
edukacyjne [...] umożliwiają osiągnięcie przez studentów efektów uczenia się, w tym przygotowanie do prowadzenia działalności naukowej lub udział w tej działalności” (wskaźnik 5.1.i).

Porównanie polskiego modelu kształcenia $\mathrm{z}$ osiągnięciami i sposobami działania innych uczelni europejskich musi prowadzić do niezbyt optymistycznych wniosków, także w odniesieniu do stosunków międzynarodowych, wykładanych na typowym dla naszych uniwersytetów profilu ogólnoakademickim. Ani ustawodawca, ani minister właściwy do spraw szkolnictwa wyższego, ani też instytucja odpowiedzialna za doskonalenie jakości kształcenia nie biorą pod uwagę zmian, jakie zaszły na zachodnich uczelniach. Uniwersyteckie kształcenie badawcze musi zostać oparte o praktykę, a w tym wypadku - o praktykę prowadzenia zaawansowanych rzeczywistych badań naukowych. Dostęp do infrastruktury, publikacji i zasobów edukacyjnych jest warunkiem sine qua non, ale absolutnie nie wystarcza to, by zaoferować rzetelne wykształcenie przygotowujące do samodzielnego planowania i wykonywania analiz zjawisk zachodzących w sferze relacji międzynarodowych. Jeśli chcemy nadążać za postępem, który dokonał się na tym polu w innych krajach, to uczelnie muszą zrozumieć, że kształcenie na profilu ogólnoakademickim musi opierać się na praktyce - praktyce prowadzenia badań pod okiem doświadczonych naukowców. Badania powinny zostać zdefiniowane tak, jak postulują Brytyjczycy - jako rzeczywiste współtworzenie postępu w nauce. W przeciwnym wypadku uprawiana w Polsce dyscyplina naukowa stosunki międzynarodowe (niezależnie od tego, czy w ministerialnym wykazie zostanie wymieniona jako odrębna) pozostanie na marginesie nauki europejskiej i światowej, i to nie tylko ze względu na ograniczone zasoby, do jakich mamy dostęp na swoich uczelniach ${ }^{29}$.

\section{Bibliografia}

Academic ranking of world universities 2019, „Academic Ranking of World Universities” [online, dostęp: 1 IX 2019], dostępny w internecie: <http://www.shanghairanking.com/ ARWU2019.html>.

Curriculum and courses, „Rudboud University” [online, dostęp: 1 IX 2019], dostępny w internecie: $<$ https://www.ru.nl/english/education/masters/international-relations/curriculum-and-courses/>.

29 Rozporządzenie Ministra Nauki i Szkolnictwa Wyższego z dnia 20 września 2018 r. $w$ sprawie dziedzin nauki $i$ dyscyplin naukowych oraz dyscyplin artystycznych, Dz.U. 2018, poz. 1818. 
Description of Master's Programme „Peace and Conflict Studies and International Relations”, „University of Tübingen” [online, dostęp: 1 IX 2019], dostępny w internecie: <https:// uni-tuebingen.de/en/faculties/faculty-of-economics-and-social-sciences/subjects/department-of-social-sciences/ifp/institute-of-political-science/people/ipol/course-programme/master-peace-research-and-international-politics/description-of-masters-programmpeace-and-conflict-research-and-international-relations/>.

Dla kandydatów, „Instytut Nauk Politycznych i Stosunków Międzynarodowych Uniwersytetu Jagiellońskiego" [online, dostęp: 1 IX 2019], dostępny w internecie: <https://inp.uj.edu. $\mathrm{pl} /$ kandydaci $>$.

European Commission, Peer review. Poland's higher education and science system. Horizon 2020 policy support facility, Publication Office of the European Union, Luxembourg 2017.

Friedensforschung damals und heute Selbstverständnis, „University of Tübingen” [online, dostęp: 1 IX 2019], dostępny w internecie: <https://uni-tuebingen.de/fakultaeten/wirtschaftsund-sozialwissenschaftliche-fakultaet/faecher/fachbereich-sozialwissenschaften/ifp/institut/lehrende/ipol/lehrangebot/master-friedensforschung-und-internationale-politik-mafip/ friedensforschung-in-tuebingen/>.

International Relations MSc, „University of Glasgow” [online, dostęp: 1 IX 2019], dostępny w internecie: <https://www.gla.ac.uk/postgraduate/taught/internationalrelations/\#tab=why>.

Master's specialisation in International Relations, „Rudboud University” [online, dostęp: 1 IX 2019], dostępny w internecie: <https://www.ru.nl/english/education/masters/ international-relations/>.

Periodisk programevaluering av Master of Philosophy in Peace and Conflict Studies (PECOS), „Oslo University” [online, dostęp: 1 IX 2019], dostępny w internecie: $<$ https:// www.uio.no/english/studies/programmes/peace-master/programevaluering/Periodisk. programevaluering $06>$.

Political science. Nijmegen School of Management: Radboud University, QANU, Utrecht 2017, dostępny również w internecie [dostęp: 1 IX 2019]: <https://search.nvao.net/files/5a93fd067337d_006099\%20 r.pport\%20Radboud\%20wo-ma\%20Political\%20Science.pdf $>$.

Program. Wskaźniki, dostępny w internecie [dostęp: 1 IX 2019]: <https://ela.nauka.gov.pl/ assets/csv/file/P1.csv>.

Programme structure, „University of Oslo” [online], 12 X 2018 [dostęp: 1 IX 2019], dostępny w internecie: <https://www.uio.no/english/studies/programmes/ces-master/structure/>.

Promoting research and innovation across Europe. Founding vision, „The Guild” [online, dostęp: 1 IX 2019], dostępny w internecie: <https://www.the-guild.eu/about/vision/the-guild---founding-vision.pdf $>$.

Rozporządzenie Ministra Nauki i Szkolnictwa Wyższego z dnia 20 września 2018 r. w sprawie dziedzin nauki i dyscyplin naukowych oraz dyscyplin artystycznych, Dz.U. 2018, poz. 1818.

Rozporządzenie Ministra Nauki i Szkolnictwa Wyższego z dnia 27 września 2018 roku w sprawie studiów, Dz.U. 2018, poz. 1861.

Rybkowski R., Kędzierski M., Zawodówki: reaktywacja. Rola wyższych szkół zawodowych w rozwoju społeczno-gospodarczym Polski, Centrum Analiz Klubu Jagiellońskiego, Kraków 2017 (Raport, 4/2017).

UK Quality Code for Higher Education, „QAA” [online], 3 V 2018 [dostęp: 1 IX 2019], dostępny w internecie: $<$ https://www.qaa.ac.uk/quality-code>.

UK Quality Code for Higher Education, part B: Assuring and enhancing academic quality, chapter B11: Research degrees, „QAA” [online, dostęp: 1 IX 2019], dostępny 
w internecie: <https:/www.qaa.ac.uk/docs/qaa/quality-code/chapter-b11_-research-degrees.pdf?sfvrsn $=5802 \mathrm{f} 781 \_8>$.

Ustawa z dnia 20 lipca 2018 roku - Prawo o szkolnictwie wyższym i nauce, Dz.U. 2018, poz. 1668 z późn. zm.

Why choose this programme? [Development, Environment and Cultural Change], „University of Oslo" [online, dostęp: 1 IX 2019], dostępny w internecie: <https://www.uio.no/english/ studies/programmes/ces-master/why-choose/>.

Why choose this programme? [Peace and Conflict Studies], „University of Oslo” [online, dostęp: 1 IX 2019], dostępny w internecie: <https://www.uio.no/english/studies/programmes/ peace-master/why-choose/>.

Wskaźniki spetnienia standardów jakości ksztatcenia, „Polska Komisja Akredytacyjna” [online, dostęp: 1 IX 2019], dostępny w internecie: <http://www.pka.edu.pl/wp-content/uploads/2019/04/OP_wskaźniki_spełnienia-standardów_24_02_final.pdf>. 